International Journal of Social Sciences and Humanities
Available online at http://sciencescholar.us/journal/index.php/ijssh
Vol. 3 No. 2, August 2019, pages: 128 135
e-ISSN: 2550-7001, p-ISSN: 2550-701X
https://doi.org/10.29332/ijssh.v3n2.302

\title{
Brain and Learning
}

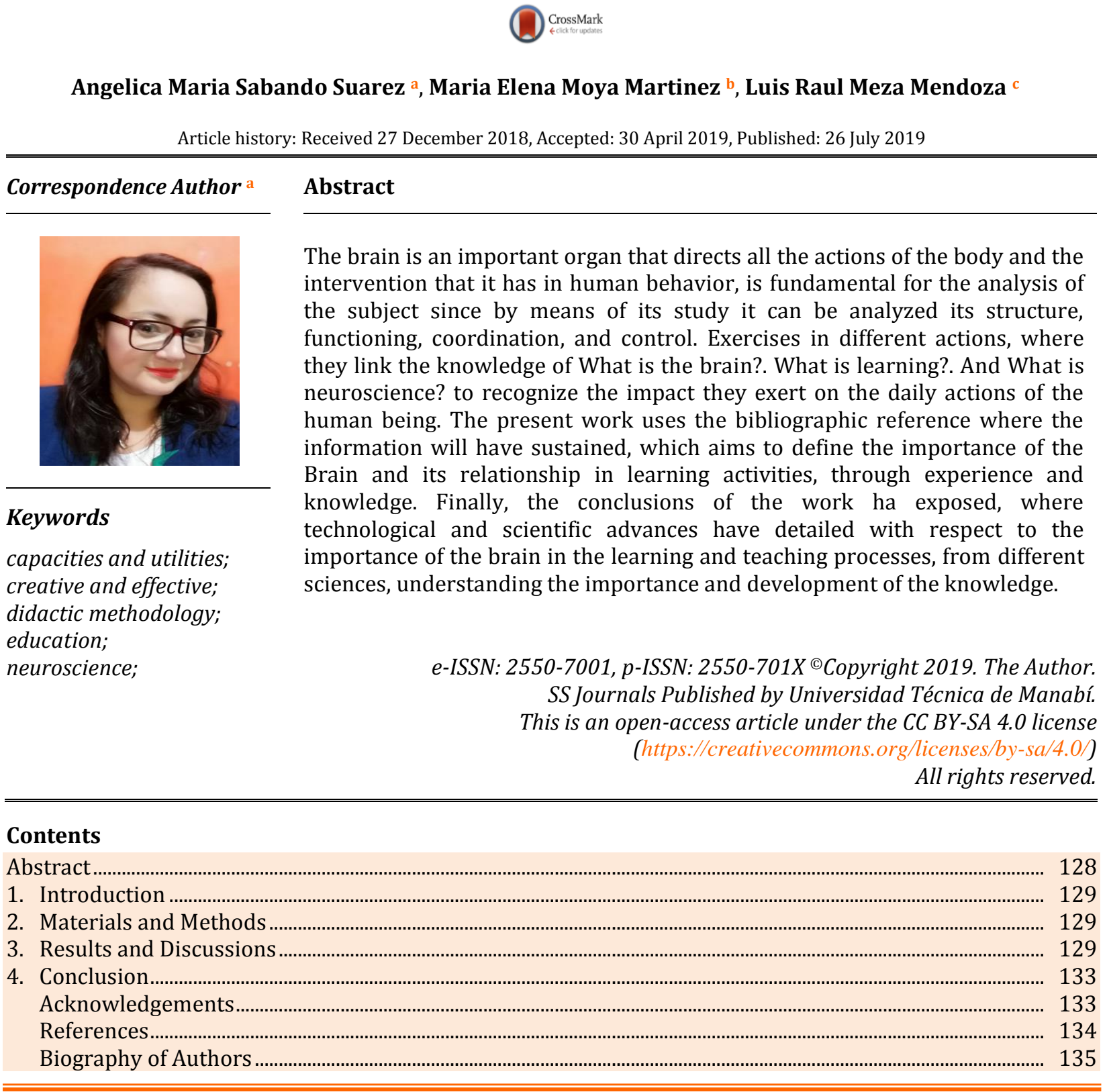

a Pontificia Universidad Católica del Ecuador, Portoviejo, Ecuador

b Pontificia Universidad Católica del Ecuador, Portoviejo, Ecuador

c Pontificia Universidad Católica del Ecuador, Portoviejo, Ecuador 


\section{Introduction}

The brain controls from holistic concepts, creativity, to the analysis, execution and processing and awareness training the thoughts and language, since this organ is the only one that is able to learn by itself in an innate way and also teach itself the new knowledge obtained by the external environment.

The storage, processing, and evocation of information are processes that have performed based on microseconds, by means of the electrical connections between the neuron transmitters that produce through the synapse so that the transmission of information is finally carried out.

The study of the general functioning of the brain and its relationship with educational processes, dedicated to meaningful learning, was used analysis and interpretation, with the aim of defining the importance of this organ within the learning activities, through experience and the knowledge, the teacher must have an understanding, that is the brain, as learning occurs within it and the processes of neuroscience in education, these are key and important aspects in the development of research, as it aims to give reflection on the functioning of the brain and how this body is capable of generating learning, by investigating the capabilities and usefulness it produces, such as language, reasoning, memory, imagination; resolution of problems among other aspects, the role it plays as an active agent of that process and how it seeks to improve the quality of the teaching function, including the didactic methodology that is carried out to achieve it.

Neuroscience and education have linked giving diverse contributions to teaching - from two perspectives that work for the same result, the achievement of learning. Significant learning occurs when learners associate new information with the information they already have a process that will allow them to establish their own concept, which they can apply in their daily lives, these learning can be affected by the socioeconomic environment that influences the academic performance, which may be limiting and causing problems in the acquisition of this teaching-learning process (Suma et al., 2018; Astawa, 2019).

\section{Materials and Methods}

The methodology used in this research is qualitative because it does not require experimentation and focuses on obtaining information for the analysis and interpretation of the information collected. Theoretical method was applied, for facilitating the definition of the data, and the explanation of an event from its research and Historical - Logical Method for facilitating linking the contents from different stages of the research and Method of Analysis and synthesis facilitates the analysis of the research from its elements relating it to critical and reflective analysis verified in the bibliographic references of the research and Induction Method - deduction because the research can be raised from the reasoning that covers the particular and raise the research to the general, as well as a research from the general to the particular information and the systematic method all research must make sense and link their processes through the method.

\section{Results and Discussions}

Within the study of the brain and learning is important to identify these elements separately in order to have a knowledge of each of them and then subsequently link them: What is the brain? What is learning? What is neuroscience? These will be the key questions that will have developed in the research.

In the course of answering these questions will be understood the importance of brain functionalities in relation to learning and how it influences the teaching-learning of students. Therefore, the purpose of linking the study of the brain is to help understand the actions of the human being and his behavior in society (Arias, 2011; Herianto, 2017; Gani et al., 2018).

Incursionary in the study of the brain and therefore the neuroscience that is the science that studies the composition of the brain and the development of the different activities, characteristics, and formation of the various voluntary and involuntary processes of the human body, the same ones that generate social behavior.

Suarez, A. M. S., Martinez, M. E. M., \& Mendoza, L. R. M. (2019). Brain and learning. International Journal of Social Sciences and Humanities, 3(2), 128-135. https://doi.org/10.29332/ijssh.v3n2.302 
The brain is the most complex organ in humans because it is responsible for controlling and coordinating body movements and processing sensory information. The brain is an extraordinary organ that facilitates voluntary and involuntary actions of daily life, unconscious functions such as breathing, blood circulation, as well as voluntary ones such as speaking and making decisions, due to the chemical and electrical functions that our brain (Arias, 2011; Iriani et al., 2018).

The brain is responsible for learning, cognitive processes, memory and emotions, its operation is performed through the interaction between its two hemispheres cerebral: the right and the left, each hemisphere has other fissures, but not so deep, that they divide the cerebral cortex into different lobes.

The right hemisphere is integrating, with a holistic conception of reality, it is a regulator of operations that offers creative strategies characteristic of an innovative way of thinking. The left hemisphere is analytical, executive and conscious; it is activated when information about the logical language is processed: languages, mathematics, computation; both hemispheres work together exchanging information, which the human being uses in his daily life.

The hemispheres of the brain work together exchanging information, which the human being uses in his daily life. The brain is the only organ capable of learning new knowledge, as well as teaching itself (Campos, 2013).

This has allowed the human brain to develop various functions that are fundamental for communication between individuals, in order to facilitate their understanding neuroscience, is responsible for investigating the different processes performed by the brain. Neuroscience through a line of research establishes the correlation between brain development and the integral development of children since their early childhood. (Campos, 2013).

The brain allows learning, the generation of knowledge and reflection of events, in addition to the events that occur in life through experience, the understanding of learning begins; this is defined as the process of acquiring knowledge, skills, values, and attitudes. Behavioral change occurs when obtaining new knowledge that allows the person to be guided according to the practice of new learning (Leiva, 2005).

Learning as a behavioral change influenced by events that occur in the environment, allow the intervention of the brain to perform functions such as, learn and memorize product of changes in neurons and their contacts with other neurons forming networks that extend to Throughout many areas of the brain, their interaction is known as "synapses," which transmit information from one neuron to another.

The brain produces more complex responses when environmental stimuli are more demanding. The brain's ability to store information is unlimited and malleable. The ability to acquire, train, preserve and remember information depends on endogenous and exogenous factors, the experiences and the learning methodology used by the educator. The brain has different memory systems, which can store from a small amount of data to an unlimited number of them.

Memory is one of the most complex functions of the brain to retain information; through the synapses performed by neurons, classified memory in long and short term, the first stage of storage is the record where the sensory information is transformed, The second stage is the retention that aims to conserve, recover knowledge when necessary, and the collection of stored information, ie remember, evoke and recognize the information acquired.

The brain through its structure and connections perform processes from which learning has obtained, memory to modify the structure of a person forever (Villalobos, 2015). Knowing how the process of acquisition, storage and evocation takes place will allow the teacher to develop learning proposals according to the needs of the group of students.

That is it is necessary that the teacher-student understand how the brain performs the different functions, its organization in systems and how these systems allow it to perform all the necessary functions for the integral development of the human being, for that reason knowledge about the structure and functioning of the brain will give the educator the basis or foundation to undertake a new teaching-learning style, a new classroom environment and, most importantly, a new opportunity for the integral and human development of his student. The complexity of the brain lies in its constant change, modeled on the experiences of childhood and through life (Eraso, 2013).

However, this learning in many cases is usually partial because with the passage of time our brain will receive more information and forgetting others, in each of its aspects and characteristics, adds the fact that memory is not a true copy of "objective" reality, but only a record of how it was experienced and known 
through one's experience. As it has manifested, the information is deposited, processed and constantly reinterpreted in the memory, according to the new experiences, motivations, concepts, and emotions.

The learning of the brain is gradual for a reason the knowledge should go from the simplest and most concrete to the most abstract and complex as an example of it at a simple level, the child learns to add three plus three, to recognize the $t$ in the word tit, interact with other children and tie shoelaces.

Students learn to solve problems, write papers, perform activities of their daily life, ride a bike and cooperate with collective projects in this way we understand that throughout our lives generate learning, however, this issue generates much controversy because no definition of Learning is accepted by all theorists, researchers, and education professionals;

On the other hand, as the linkage of these two elements is the Neuroeducation this has defined as the union between basic neuroscience and its applications in education to harmonize the teaching methodologies of teachers with the learning techniques of the students. Among the new disciplines is the Neuroeducation considered an interdisciplinary and transdisciplinary that integrates the science of education responsible for the neurocognitive part of the human person, contributes to the study of the brain and the creation of theories that influence the processes of current education (Pallarés, 2015).

This process involves the formation of "neuroeducation" that are among the teachers interested in neuroscience research and among neuroscientists interested in education, that is, the door opens up to a new profession and a new type of experts. In this sense, Neuroeducation is promoted as a new line of thought and action whose main objective is to bring educational agents to the knowledge related to the brain and learning, considering the union between Pedagogy, Cognitive Psychology, and Neuroscience.

It is necessary that teachers take into account these aspects that intervene in educational processes in order not only to generate students with broad knowledge capabilities but also integrity and values-based that is to say that seeks knowledge that is complete and sufficient to face successfully all the tasks that the current time demands.

The life experiences of a person literally lead him to make new connections between neurons that transmit several signals, Saavedra states that all new knowledge is based on previous experiences, but there are also innate actions determined by the recognition of certain actions (Saavedra, 2001).

As is known, the experimental sciences focus more on "how phenomena occur" then on "why and why they happen", to understand why it is necessary to learn we must resort to the theory of evolution, which, although not raises extra mundane purposes, points out that living organisms evolve to better fulfill their intrinsic purpose of surviving and reproducing.

It poses the question "why you learn" from an evolutionary point of view, there may be several hypotheses that explain this biological need to learn, basically, these hypotheses show that learning is set in motion and developed to know, know and be able finally to act, which is the decisive step in the task of adapting. For the "need for adjustment" where they are determined according to the need, the brain has evolved to accompany and face the challenges of the environment, to educate and educate, to make the human being understand the enormous potential it inside.

As the central axis of research in Neurosciences the brain becomes the guide of new research, which is leading neuroscientists to be able to conceive thoughts, emotions, feelings and movements among many other skills that make us different from the rest species on earth This approach between educators and neuroscientists has begun to bear great dividends as soon as neurosciences began to reach educational environments.

Currently, educators can already understand lateralization as something relative, since the brain works as a whole, recruiting different areas to give a specific function, the training and training of educators in Neuroeducation to understand the brain mechanisms that underlie the different functions performed by the brain. Neuroeducation or educational neuroscience is an interdisciplinary study of the processes that are performed in the neuron and its relationship with psychology, education with the purpose that teachinglearning can improve in students (Martinez et al., 2018).

The knowledge that Neuroeducation brings makes the challenges seen as opportunities, because now we know that we all have a plastic brain, apt to learn as many times as necessary as long as the genetic and environmental conditions for it are given, the lessons learned are consecutive and they reside according to the external and internal agents that assimilates the brain to form there, recognize the information, store it and evoke it according to the situation.

Suarez, A. M. S., Martinez, M. E. M., \& Mendoza, L. R. M. (2019). Brain and learning. International Journal of Social Sciences and Humanities, 3(2), 128-135. https://doi.org/10.29332/ijssh.v3n2.302 
Neuroeducation by allowing the teacher to understand the particularities of the nervous system and the brain and, at the same time, relate this knowledge with the behavior of their students, their learning proposal, their attitude, the classroom environment, among other factors, it can be the initial step in teacher education and training that will make a difference in the quality of education. Table 1 shows the measurement of results according to different authors.

Table 1

Outcome measurement

\begin{tabular}{|c|c|c|c|c|}
\hline Author & Theme & Year & Interpretation & Result \\
\hline Arias & Brain and learning & 2011 & $\begin{array}{l}\text { Study the functions of the } \\
\text { brain and its interaction } \\
\text { with social behavior. }\end{array}$ & $\begin{array}{l}\text { Recognition of the } \\
\text { importance of the brain } \\
\text { and its various functions } \\
\text { within human behavior }\end{array}$ \\
\hline Fields & $\begin{array}{l}\text { The contributions of } \\
\text { neuroscience to early } \\
\text { childhood care and } \\
\text { education }\end{array}$ & 2013 & $\begin{array}{l}\text { The importance of } \\
\text { neuroscience in the study } \\
\text { of the brain and its ability } \\
\text { to learn to learn }\end{array}$ & $\begin{array}{l}\text { Study of early childhood } \\
\text { and its relation to } \\
\text { learning processes. }\end{array}$ \\
\hline Eraso & $\begin{array}{l}\text { Learning adapted to } \\
\text { the brain }\end{array}$ & 2013 & $\begin{array}{l}\text { The complexity of the } \\
\text { brain in the execution of } \\
\text { the different action of the } \\
\text { human being }\end{array}$ & $\begin{array}{l}\text { Learning through the } \\
\text { study of the brain for the } \\
\text { acquisition of new } \\
\text { knowledge. }\end{array}$ \\
\hline Leiva & $\begin{array}{l}\text { Behaviorism, } \\
\text { cognitivism, and } \\
\text { learning }\end{array}$ & 2005 & $\begin{array}{l}\text { Behavioral change through } \\
\text { the application of new } \\
\text { knowledge. }\end{array}$ & $\begin{array}{l}\text { A permanent change in } \\
\text { the behavior of people by } \\
\text { the conception of a new } \\
\text { mental scheme. }\end{array}$ \\
\hline Martínez & Neuroeducación & 2018 & $\begin{array}{l}\text { The study of neurons and } \\
\text { psychological and } \\
\text { cognitive processes for } \\
\text { new learning. }\end{array}$ & $\begin{array}{l}\text { The teaching-learning } \\
\text { process from the study of } \\
\text { neurons and brain } \\
\text { functioning. }\end{array}$ \\
\hline Pallares & $\begin{array}{l}\text { Educational } \\
\text { participation }\end{array}$ & 2015 & $\begin{array}{l}\text { The participation of } \\
\text { education and its } \\
\text { interdisciplinary study of } \\
\text { the human brain }\end{array}$ & $\begin{array}{l}\text { The formation of new } \\
\text { knowledge from the } \\
\text { study of the functioning } \\
\text { of the brain. }\end{array}$ \\
\hline Villalobos & & 2015 & $\begin{array}{l}\text { The connection made by } \\
\text { the brain to generate } \\
\text { knowledge through } \\
\text { neurons to modify the } \\
\text { thinking of a person. }\end{array}$ & $\begin{array}{l}\text { The study of the brain } \\
\text { and its relation to the } \\
\text { change of human } \\
\text { thought, the intervention } \\
\text { of neurons. }\end{array}$ \\
\hline Saavedra & $\begin{array}{l}\text { Learning based on the } \\
\text { brain }\end{array}$ & 2001 & $\begin{array}{l}\text { There are innate reactions } \\
\text { of the human being, as well } \\
\text { as acquired through new } \\
\text { learning. }\end{array}$ & $\begin{array}{l}\text { Recognizing the } \\
\text { importance of the brain } \\
\text { can establish the way in } \\
\text { which it generates new } \\
\text { knowledge. }\end{array}$ \\
\hline
\end{tabular}

The importance of the study of the brain for the formation of memory and significant learning that occurs from different stages of life, naturally those with which we are born, and acquired over time through external 
processes that can model the behavior of the human being, the study of neuroscience allows to identify the neurological, cognitive and behavioral processes that form the individual behavior of people.

Learning, the brain and neuroscience have studied as interdisciplinary to determine the interrelation that exists between the different cognitive processes, and the generation of new knowledge, based on the development of the conscience and action of the human being, from the different perspectives of the knowing.

Behavioral change occurs when obtaining new information, the study and understanding of the characteristics of human development, the way of learning, interest, creativity, curiosity and the forms of communication are aspects

\section{Conclusion}

Current education is constantly changing to the technological and scientific advances, the same ones that generate indispensable skills and abilities in the learners, of a flexible nature since they allow both teachers, parents and the educational community to be in constant participation in an innovation process that requires adaptation from education to sustainable change over time.

In reference to this and with the advances that have been taking place in both the educational and scientific fields, new hypotheses arise that try to explain the importance of the brain in the learning and teaching processes, that is, a relationship between these two areas is created giving This way step to the Neuroeducation where it is tried to explain the importance that the teachers know the operations and structures of the brain with the purpose of understanding how the learning arises and the different forms of the same one wherefrom this knowledge the teachers look for to change the methodological strategies at the time of teaching, so that they can be received in a better way by the student.

In conclusion, the relationship between brain and learning has clearly established, resulting in a new field of education as well as the different sciences, understanding the importance of their interrelation today and how these advances have allowed education to be developing and changing in order to generate students apt in knowledge and values.

\section{Acknowledgments}

The author would like to thank the editorial boards' team of IJSSH for their valuable time, support and advice in completing the present study.

Suarez, A. M. S., Martinez, M. E. M., \& Mendoza, L. R. M. (2019). Brain and learning. International Journal of Social Sciences and Humanities, 3(2), 128-135. https://doi.org/10.29332/ijssh.v3n2.302 


\section{References}

Arias, L (2011) Calos Belmonte 2011 module: brain and learning. Recovered from https://expedicionatlantida.files.wordpress.com/2011/04/cerebro-aprendizaje-1-lilianaarias1.pdf

Astawa, D. N. W. (2019). Influence of mind mapping method implementation on learning results social science is required from students interest. International Research Journal of Management, IT and Social Sciences, 6(3), 94-100. https://doi.org/10.21744/irjmis.v6n3.637

Campos, A (2013) The contributions of neuroscience to early childhood care and education. Retrieved from https://www.unicef.org/bolivia/056_NeurocienciaFINAL_LR.pdf

Eraso, I (2013) Learning adapted to the brain. Recovered from https://emocreativos.com/2013/02/12/aprendizaje-adaptado-al-cerebro/

Gani, A. A., Ibrahim, N., \& Khaerudin, -. (2018). Multimedia use and learning styles on learning achievement in social studies. International Journal of Social Sciences and Humanities, 2(2), 187-193. https://doi.org/10.29332/ijssh.v2n2.163

Herianto, E. (2017). The effect of learning strategy, achievement motivation, and communication skill toward learning outcomes on the course PMPIPS-SD at PGSD. International Research Journal of Management, IT and Social Sciences, 4(5), 1-11.

https://dialnet.unirioja.es/descarga/articulo/4835877.pdf

Iriani, D. H., Syahdan, -, \& Nuriadi, -. (2018). The effect of early English learning on psychology. International Journal of Social Sciences and Humanities, 2(1), 65-74. https://doi.org/10.29332/ijssh.v2n1.82

Leiva, C. (2005) Behaviorism, cognitivism and learning. Magazine Technology in March.18 (1). Recovered from

Martínez A, and Piqueras J, and Delgado B, and García J. (2018). Neuroeducation: contributions of neuroscience to curricular competences. 48 (2) Published Faculty of Education and Humanities of Campus de Melilla. Recovered from https://dialnet.unirioja.es/servlet/articulo?codigo=6930418

Pallares, D. (2015). Educational Participation School board review of the state the relationship between family and school 4 (7). 4 Recovered repositori.uji.es/xmlui/bitstream/handle/10234/155185/71364.pdf?sequence=1 ...

Saavedra M. (2001). Learning Based on the brain. Journal of Psychology, 10 (1). Retrieved from http://www.redalyc.org/pdf/264/26410111.pdf

Suma, K., Suriyasmini, N. M., \& Pujani, N. M. (2018). The effect of conceptual change text on improving student understanding of electricity concepts and learning motivation. International Research Journal of Engineering, IT \& Scientific Research, 4(6), 33-43. https://doi.org/10.21744/irjeis.v4n6.337

Villalobos J. (2015). Francisco Mora, 2013. Neuroeducation, you can only learn what you love. Madrid. Journal of the Faculty of Psychology, (18), 155-158. Recovered from https://dialnet.unirioja.es/servlet/articulo?codigo $=6170873$ 


\section{Biography of Authors}

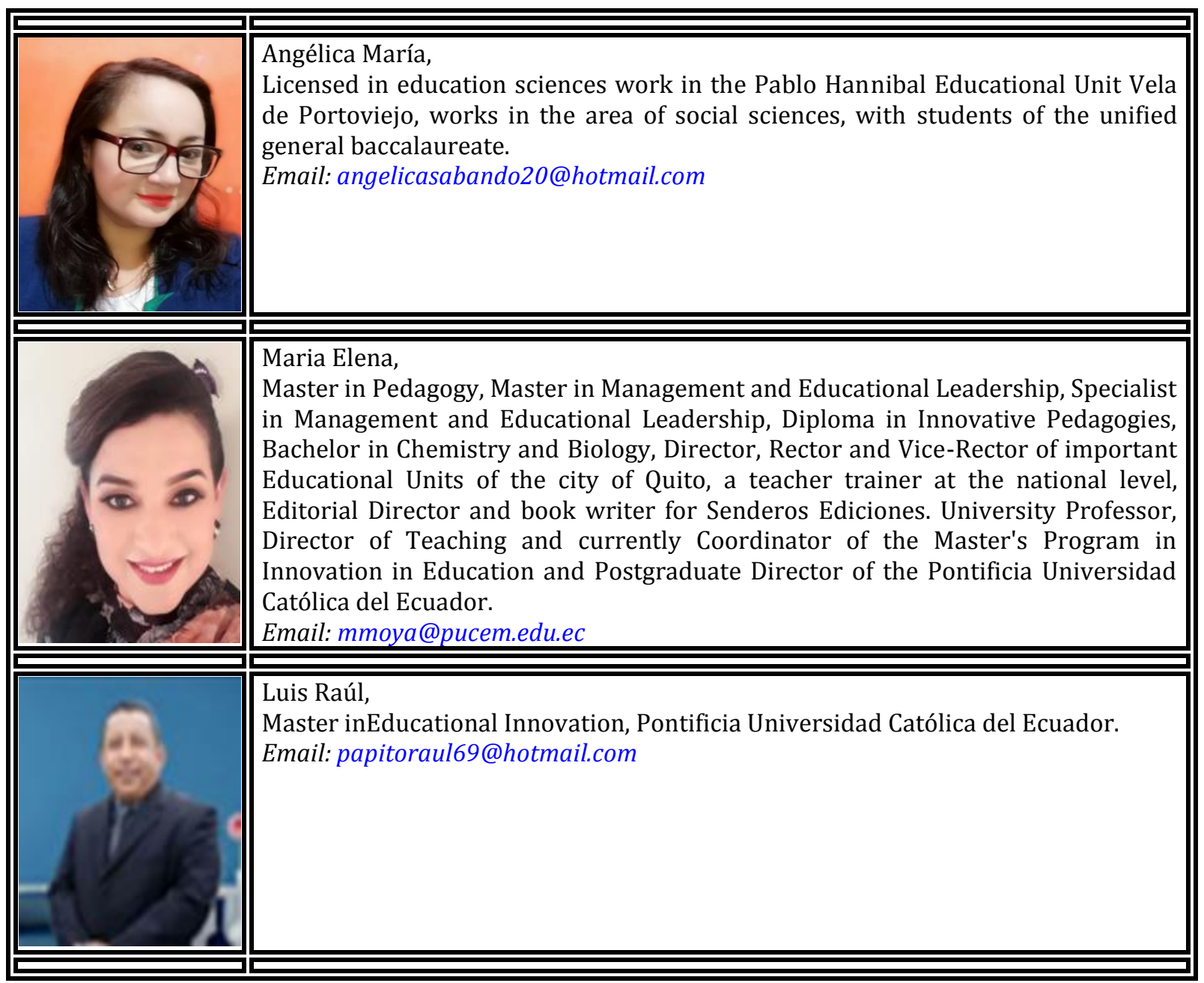

Suarez, A. M. S., Martinez, M. E. M., \& Mendoza, L. R. M. (2019). Brain and learning. International Journal of Social Sciences and Humanities, 3(2), 128-135. https://doi.org/10.29332/ijssh.v3n2.302 